Research Article

\title{
An Innovative Conceptual Model to Structure Financing Package of Infrastructure Projects
}

\author{
Hanieh Soleymani, ${ }^{1}$ Mehdi Ravanshadnia ${ }^{1},{ }^{1}$ and Mehdi Montazer ${ }^{2}$ \\ ${ }^{1}$ Department of Construction Engineering and Management, Faculty of Civil Engineering, Science and Research Branch, \\ Islamic Azad University, Tehran, Iran \\ ${ }^{2}$ Department of Law, Damavand Branch, Islamic Azad University, Damavand, Iran
}

Correspondence should be addressed to Mehdi Ravanshadnia; ravanshadnia@srbiau.ac.ir

Received 31 July 2021; Revised 19 August 2021; Accepted 14 September 2021; Published 22 October 2021

Academic Editor: S. Mahdi S. Kolbadi

Copyright (C) 2021 Hanieh Soleymani et al. This is an open access article distributed under the Creative Commons Attribution License, which permits unrestricted use, distribution, and reproduction in any medium, provided the original work is properly cited.

\begin{abstract}
Understanding the correct way to determine the financing package for infrastructure projects, identifying proper processes, resources, techniques, and instruments to realize successful financing approaches, and private sector participation in providing development infrastructures are irrefutable. The main purpose of this study is to present a comprehensive model covering these complex issues. To this end, using the library studies, receiving expert opinion, and recognizing international financing processes, information was gathered on this subject; therefore, in this paper, the model of designing financing package for infrastructure projects is processed and identified, and designing the financing structure is closely related to the ownership structure of the project and its guaranteed package. These will change in a repeatable process until the end of the preparation phase and sometimes in project steps. The ownership of the infrastructure projects is determined by this repeatable process, which defines initial sponsors, costs, and benefits for partners, types of financial instruments, and techniques and evaluates risks and capital structure. In this paper, we suggest a model to help practitioners more effectively and systematically finance infrastructures. The development of guidelines and information resources in this field is one of the effective measures to build capacity and eliminate possible ambiguities and misunderstandings about public-private partnership.
\end{abstract}

\section{Introduction}

Infrastructure plays a significant position in the progress and the growth of gross domestic product (GDP) of a country. Total infrastructures involve all the prerequisites to effective functionality in competency and development of market economies [1]. On the other hand, infrastructures require a vast amount of resources to get involved. The profits of these large investments are considerable, but these profits are obtained in the long term [2]. In developing countries, the private sector does not recognize it as a proper long-term period of return on investment (the private sector does not prefer long-term profit.), or it lacks the financial instruments to handle these projects. Therefore, the government is expected to accept part of the commitments to implement these projects in order to create a favorable condition for growth. However, government revenues from all sources, including a level of politically tolerable taxes, are less than enough to be able to fund infrastructure constructions. As a result, the problem we are facing is how to equip the private sector for this purpose. The cost-effective financing process, irrespective of the infrastructure developer type, needs a clear overall trend in terms of financing planning [3].

Technological advances that have already resulted in dramatically reduced transaction costs and advances in the theory and practice of finance that rely on low transactions costs are likely to produce wide-ranging institutional changes in the future [4]. While it may be hard to believe that the pace of general financial innovation during the past few decades can sustain itself into the future, there are reasons to believe that it can, because it is rooted in 
fundamental economic factors [5]. Pension reform is currently a high priority issue in several European countries (e.g., Italy, Germany, and France) that have relied heavily on pay-as-you-go systems of retirement income provision in the past. As the proportion of the elderly in their population increases in the next few decades, these systems will come under tremendous strains that are likely to lead to institutional change. And in the developing nations of Asia and Africa, some of which have had no formal pension system at all, institutional reforms are being considered to supplement the informal systems of family provision of old-age income.

\section{Materials and Methods}

2.1. Analyzing the Business Environment. Similarly, the difference between corporate financing and project financing in developing countries is declining [6]. Most of the project sponsors are willing to exit project debts from their balance sheets. On the other hand, project financing has turned out to be extremely difficult for infrastructure projects. Sponsors can mobilize equity and debt financing more easily when they draw on the creditworthiness of parent companies [7]. Therefore, corporate financing and project-based financing are converging toward an arrangement of limited corporate responsibilities, in the form of limited-recourse financing and other types of sponsorship [8]. The factors that should be taken into account in the analysis of the business environment are presented in Figure 1.

A public-private partnership can be an effective approach to deal the projects with modern agricultural development in Sub-Saharan Africa [9]. Financial analysis of lower and higher capital demanding scenarios and testing of the impact of changes in the critical drivers of costs and revenues showed that a combination of staple crops and cash crops can be found to balance national food security policy targets and financial appeal for private partners in a mutually satisfactory venture capital. Flexibility, driven by timely big data feedbacks, contributes to reducing the intrinsic rigidity of long-termed PF healthcare investments. Healthcare is a highly networked and systemic industry that can benefit from interacting with big data that provide timely feedbacks for continuous business model reengineering, reducing the distance between forecasts and actual occurrences [10]. This paper aims to answer two questions: how to share the benefits between the contractual parties and reach an optimal long-term contractual agreement? And which type of contract ensures a consistent risk transfer to the private partner, allowing the PA an "off balance" accounting treatment? The research questions are answered through the development of a mathematical equation that can calculate the optimal percentage of benefits sharing between partners in a long-term contractual agreement [11].

The public infrastructure companies that traditionally financed their projects through government-sponsored or government-backed loans currently provide financing sources such as commercial banks, release, and limited use of financial bond to the private sector and even stock markets
[12]. In contrast, private sector investors who are expected to invest their funds in the projects often seek to use formal funding sources that also have some form of government supports; of course, this happens when sponsors of the private sector create a company jointly with government agencies in a special purpose company (SPC). Using any kind of the sources and instruments of financing has different advantages to mitigate kinds of risks [13]. The risk and cost of capital financing are two important factors in creating these differences [6]. The research tries to determine ownership structure and security packages and risk coverage instruments in PPP projects [14]. After collecting the necessary information, the process of designing the financing model was completed through interviews with international project experts and financial professionals. Model modification, verification, and validation were done through the Delphi method by a panel of experts [15]. Private and public infrastructure development companies in the world may be clearly differentiated from one another, but they are close to each other in terms of financing infrastructure projects in developing countries [6].

2.2. Ownership and Project Structures. An introduction to ownership and project structures of the premise of an unfounded project financing is inextricably linked to the ability of lenders to assess and, to an extent, control the operations of the borrowing entity [6]. This is most effectively achieved through the use of a single purpose vehicle (SPV), whose only asset is the project [16]. All project finance transactions have some level of interaction with their host government. It can be noted that one end of the spectrum is solely in respect of permitting requirements and at the other may involve a significant degree of government ownership [17]. Although single sponsors may decide to carry out a project alone, and as a matter of practice, most large projects are jointly owned or jointly controlled [18]. The reasons for selecting a joint structure include spreading the project risk among a number of participants; maximizing the benefits of a combination of skills, technology, and resources; and allowing participants to act in a project that would otherwise be beyond the capabilities of any of the individual sponsors. The ownership is affected by the particular financial, legal, accounting, and taxation objectives and concerns of the sponsors. Flexibility of management structure, the ease with which profits can be distributed, minimizing tax burdens, achieving off -balance sheet treatment, the scope of minority protection, and considerations regarding dissolution are among the issues that guide decisions about the proper project vehicle [13]. The ownership structure of a project is determined in two steps: conceptual and technical [6].

2.3. Conceptual Stage. At the conceptual stage, the power of public or private entities in attracting low cost funds and taking risks should be considered:

(i) Complete state ownership can prepare funds state (Figure 2) 


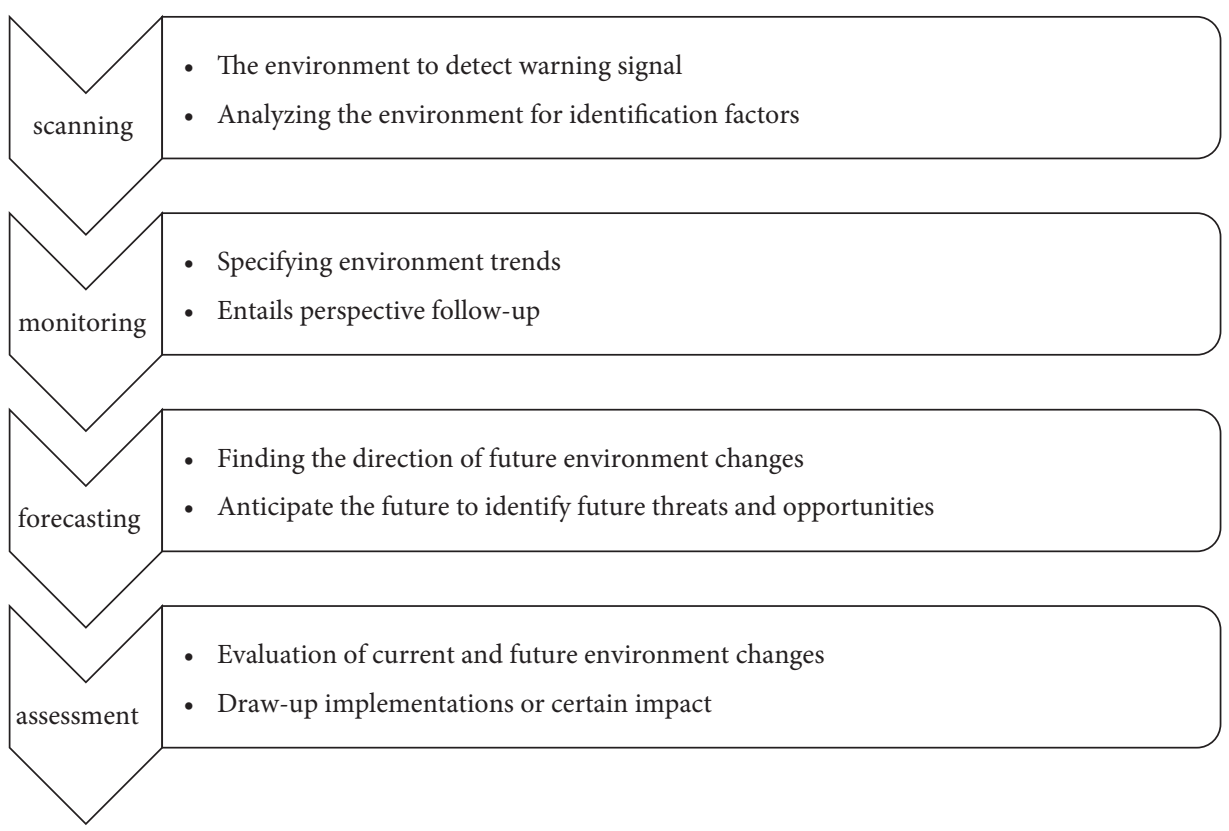

Figure 1: Flowchart for analyzing the business environment.

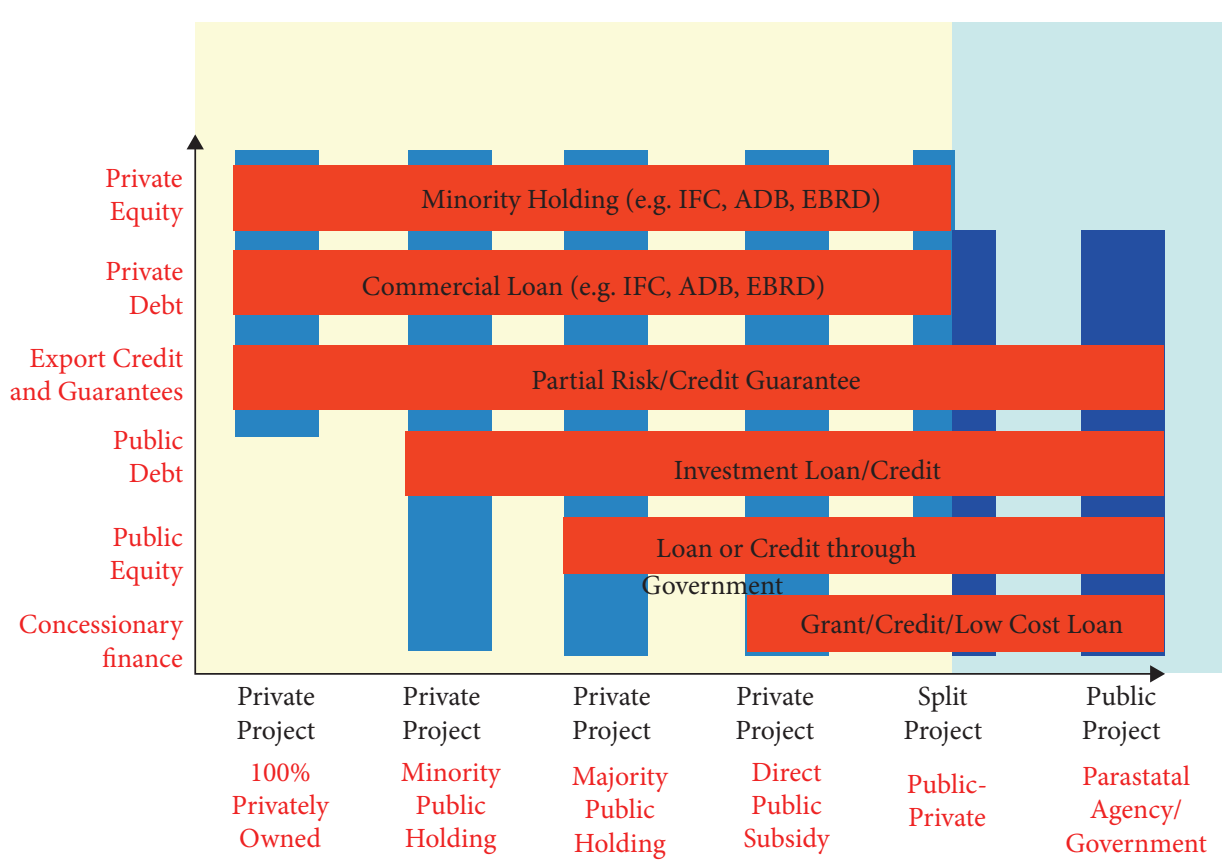

Figure 2: Public and private sector financial sources [19].

(ii) Complete private ownership cannot be easily formulated in the case of infrastructure

(iii) Partnership of public and private sector entities is becoming extremely strong

2.4. Technical Stage. At this stage, the ownership structure is determined on the basis of the sponsors' tax, accounting, and risk-sharing objectives. These arrangements should be devised to the following:

(i) Optimizing the tax position of the sponsors (ii) Achieving the risk-sharing objectives

(iii) Maximizing the level of nonrecourse financing at lowest cost

(iv) Providing protection for individual sponsors against default by other sponsors

2.5. Sources of Finance. For most infrastructure projects, sponsors start their investigation of equity and debt financing by considering the entire menu of options. Nevertheless, identification of sources appropriate to the project 
requires a systematic procedure, as explained in the following. Consider a flexible ownership structure, while a flexible ownership structure is normally assumed. Then, assessing the way government will support the project; even a declaration of national interest may help. Finally, evaluate the ability to access the multilaterals and bilateral agencies. If the multilaterals do indicate interest, project sponsors should consider an ownership structure that accommodates their requirements. In addition, approach bilateral agencies of other countries that contain well-known suppliers of goods and services needed for the project. Some bilateral provides investment financing in return for a commitment that the output of certain projects will be imported into their countries. Ask equipment suppliers to contribute as financier or shareholder. Large equipment supply companies, including trading houses, may contribute funds from their own resources. More importantly, they have substantial influence with export credit agencies of their own countries and can mobilize loans or guarantees from them. IFC or regional development banks can mobilize commercial funds. Institutions such as the IFC and the regional multilaterals have experience in quickly assessing the applicability and viability of various arrangements. Reviewing the availability of specialized funds: if available, these funds can facilitate access to both equity and debt financing. Surveying domestic investors and lenders: domestic investment and debt funds have become an important source of finance.

2.6. Legislative and Regulatory. Besides predictable political stability, financing a project requires the establishment of a legal framework required for ongoing business operation. Laws that should be reviewed by project financiers include the following:

(i) Issuance of licenses, permits, and franchises

(ii) Price regulation and controls: general business regulation

(iii) Intervention and control over businesses, in which there are foreign investors

(iv) Restriction of dividend payment to owners

(v) Rights, duties, and powers of off-take purchasers

(vi) Rights related to easements and other real property interests

(vii) Labor laws and regulations

(viii) Environmental and safety laws and regulations

(ix) Contract enforcement and repudiation

(x) Dispute resolution

(xi) Real property rights; and tax obligations

2.7. Preparing the Security Package. The security package includes some standard documents (e.g., permits and licenses) and various guarantees or agreements aimed at (1) managing and mitigating risk, (2) enabling the pledge of sponsors' assets, and (3) perfecting and enforcing the security interest (Clews, 2016). Contents of the security package will be modified continuously through the preparation process, because they are affected by the ownership and financing structures [20]. In particular, an increased government role in the project may reduce the need for arranging insurance and guarantees against political risk but may also increase the need for guarantees against commercial risks [21]. Although mitigation of all risks will have to be considered, the issue of political risk should be addressed at the outset [22]. Most investors and financiers do not take a proposal seriously until they receive some comfort that political risks are manageable. Among various commercial risks, handling the market risk and securing the corresponding guarantee instrument, such as a take-or-pay contract, are the most challenging [20].

2.8. Financing Techniques. The financing techniques are the methods and mechanisms that provide a basis for attracting funds, determining payments mechanisms, and defining the obligations and conditions of governing the financing [13]. In corporate financing, borrowing is carried out by the company as a whole, rather than by an entity created specifically to hold ownership of the new project [23]. In practice, however, most projects have limited-recourse financing (structured finance), for which sponsors commit to providing contingent financial support. The main limitation of financial resources can be categorized as follows:
(i) Time
(ii) Amount
(iii) Occurrence

2.9. Project Capital Structure. As the companies grew, the owners delegated the management of the company to the managers, and as the owners' direct control over the company diminished, control of other groups that make up the board of directors and managers was transferred, and new ownership was transferred from management to general representation [24]. Representation issues also separate from ownership control under the representation theory assumption that there is a potential conflict between shareholders 'interests and management, and that managers seek to obtain their interests from the company's shareholders, which may be guaranteed by shareholders' interests as shown in Figure 3 [25].

There is a need for financial resources to start any project. These funds can be secured through loans or partnerships with others or borrowed. A special combination of the two, including the company's long-term and short-term debt, ordinary equity, and preferred equity, is called capital structure. Simply put, a company's capital structure is the ratio of debt and equity that are the sources of a company's capital and are used to use the company's operations and assets. So, to optimize a company's capital structure, do companies decide whether they need to increase debt or equity? According to this decision, in order to increase the debt, they will take loans or issue participation bonds, and in order to increase the shareholders' equity, they will increase the capital from the cash income. The main problem for corporate finance managers is 


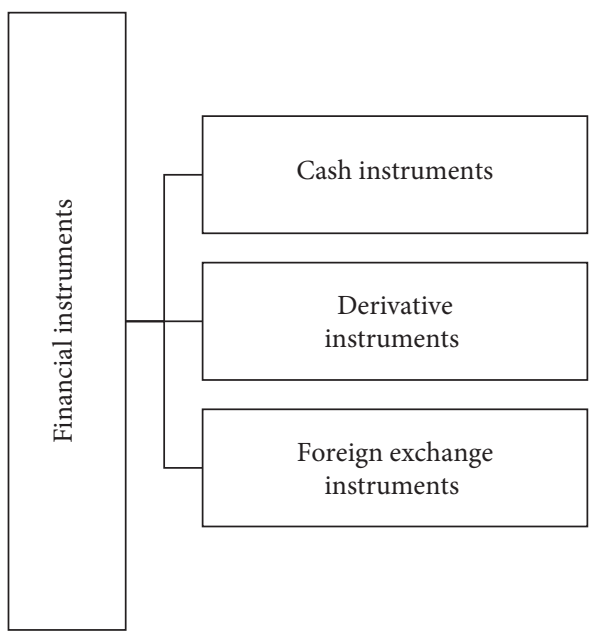

FIGURE 3: Financing instruments.

deciding how much money to borrow and what is the best combination of debt and equity. Financial managers also need to find the cheapest financial resources for the company. The capital structure is also known as the financial structure (Figure 4).

2.10. Project Finance. In recent years, financing or financing (especially project financing) has become an important method and model of attracting monetary resources and investment for the economic activities of domestic commercial institutions (such as ministries and government companies) and international [8]. Due to the role of production and development projects or infrastructure in promoting the economic growth of a country and the need to achieve the planned goals, the need for financial and credit resources is becoming more and more intense, so that today's world is witnessing intensifying competition [20]. The issue of providing financial and credit resources for the implementation of various industrial projects, especially large oil and gas industries in the upstream, intermediate, and downstream sectors, is a key issue in achieving the planned goals and is clearly clear. The first step in providing the mentioned resources is to know and be aware of the common techniques and methods in the international arena in the field of related issues [26].

Historically, project finance included bank loans, but in the current development, this perception is evolving and includes the growing proportion of project debt (including bonds/bonds, etc.). Based on the above, it can be concluded that project financing is a method of financing that does not depend on the credibility, competence, and capability of the guarantor or guarantors of the project, the parties proposing a work plan to launch the project; even its approval does not depend on the value of the assets that the guarantor or guarantors of the project wish to pledge to the capital suppliers. Instead, it is essentially a function of the project's ability to repay or repay contractual debt and recoup the investment made at a rate commensurate with the degree of risks or inherent risks involved in the economic activity (Figure 5).

According to this method, organized sourcing of an enterprise with an economy (an intermediary company or a project company) is established by the guarantor or guarantors using their share in the provision of resources or basic debt to finance the project and loans. After reviewing the cash flow of the project as the main source of loan repayment and accepting its assets as collateral, the lender will provide resources for the project. In the project financing method, an attempt is made to define the project as an independent subject and perhaps even as a business unit or an enterprise. In other words, in this method, the project is defined in such a way that it is possible to provide the necessary resources for its implementation, relying on the cash flow from the sale of future products. Therefore, in this method, attracting these resources to finance a new project must be done through the establishment of an intermediary company in a restricted manner.

2.11. Corporate Financing Model. In stock-based crowdfunding, investors share the ownership of a project by investing in and cofinancing it, and in the event of special events such as the initial public offering or sale of the property, they can become shareholders in the business. Stock-based crowdfunding is a good choice for high-growth businesses and is suitable for entrepreneurs who are thinking of developing their own small business with the goal of developing more products. Stock-based crowdfunding is done on a financing platform and on the Internet. Startup owners provide investors with a business description and details of their business (including their financial statements and business history), and by evaluating the startup information, they evaluate its growth potential and ultimately use the luck of the idea. Review the information provided for customer market acceptance. Stock-based crowdfunding is a process in which investors participate in the development of a growing business, whose shares have not been released to the market. In the next stage, during a period of 4 to 6 years and in case of special events and the success of the startup, the shareholders' capital will be converted into shares and will be liquid.

In this case, the shareholders become part of the company according to the rules and conditions. Otherwise, if the startup fails, investors will lose their capital and lose. As a result, investors are required to be aware of the risk before investing in startups and to invest in all circumstances. In reward-based crowdfunding, investors invest their capital in the startup and use its services and products for a fee. Investors' income in this method includes the startup's own products and will be differentiated according to the amount paid. This type of crowdfunding is known as the nonequity investment method and is often used in campaigns to raise the capital needed to develop software products. The noteworthy point in this model is that people do not receive a profit in return for paying their money and capital to the startup (Figure 6). 


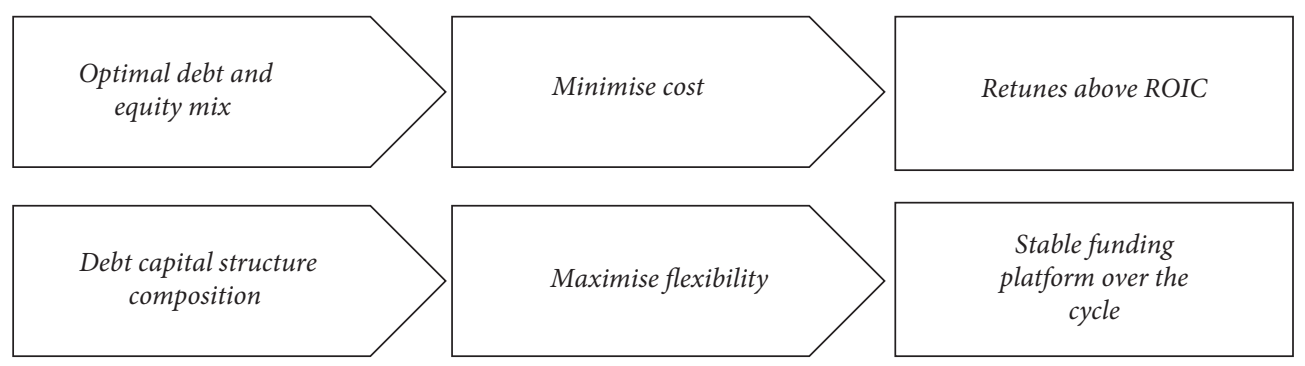

FIgURE 4: -Capital structuring.

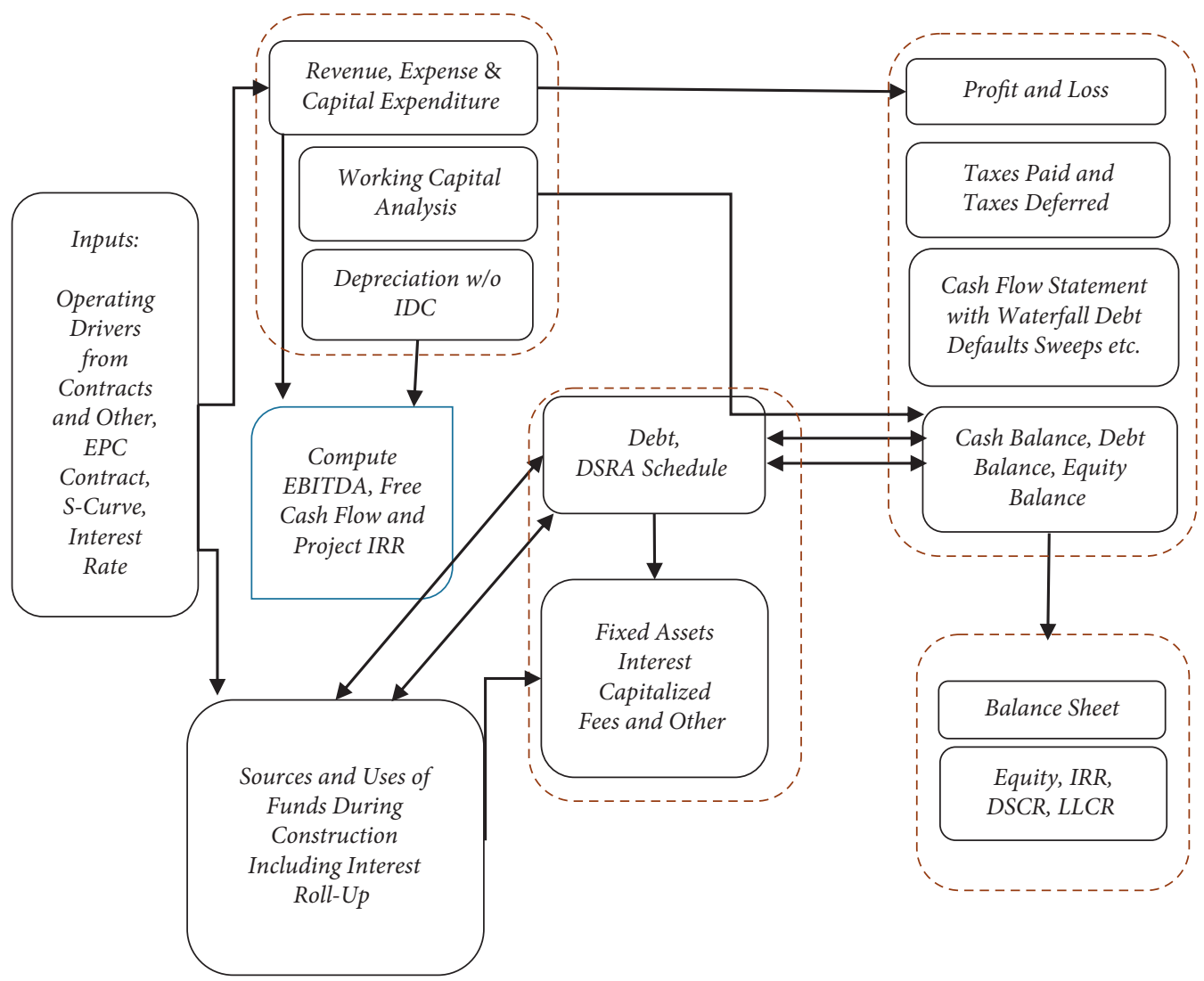

Figure 5: A project finance model (based on [27]).

2.12. Model, Results, and Discussion. The issue of financing the required projects is one of the main topics of the projects. Meanwhile, the issue of attracting foreign financial resources is a significant solution for financing high-volume projects. In a country like Iran, which needs infrastructure, attracting foreign funding is essential. What helps countries to attract foreign resources is the existence of stability and security in the economic, political, legal, and regulatory contexts and the factors and areas of interest for each industry and country to attract foreign resources. Financing can generally be in the form of borrowing from foreign banks or international financial institutions or in the form of foreign investment. In the following, different methods of external financing are examined. In borrowing methods, the investee receives a loan from the lender country or institution and is obliged to pay the installments at the due dates. In this type of method, the lender country or institution does not accept any risk, and all risks are borne by the borrower; the borrowing methods, which can be called loans, are mainly accompanied by a guarantee of repayment. The characteristic feature of these methods is that the repayment of financial resources is guaranteed by the government or commercial banks. In other words, the risk of return on investment is not borne by the investor or the supplier of financial resources, and the recipient of the financial resources through the guarantor, which is the government or the commercial bank, guarantees the obligation to repay the resources at maturity or the obligation to compensate the supplier providing funding. All foreign guaranteed loans, credit and financing facilities, etc., which are created by international banks, non-bank monetary and financial organizations, the World Bank, development banks and regions such as Islamic development, other financial institutions, and even governments, fall into this category. 


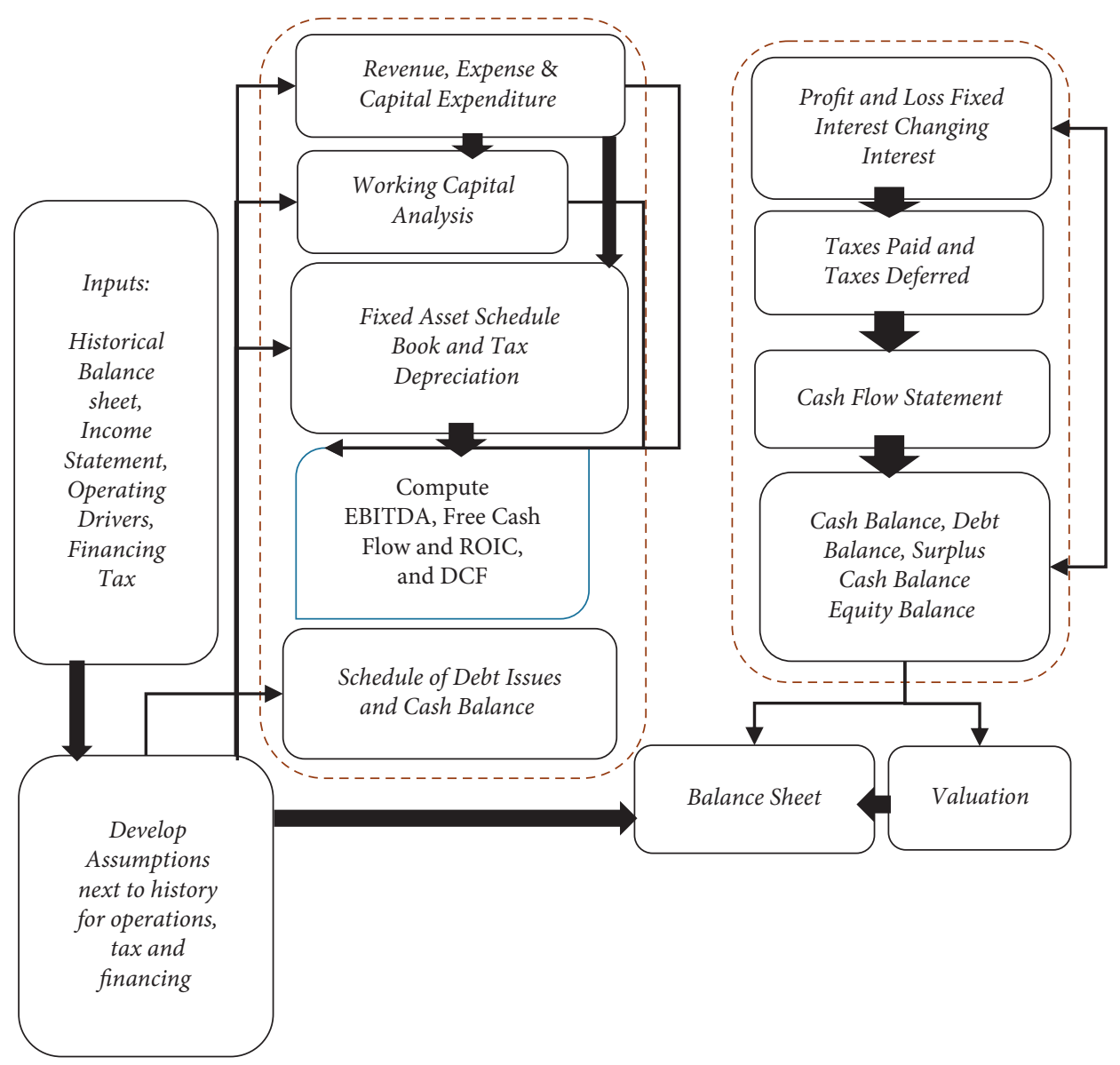

FIGURE 6: Structuring a corporate model (based on Bodmer, 2015).

The financial resources subject to this classification are considered as government debt, as well as the banking system, because of the guarantee on the balance of payments of the country (Delmon, 2011).

From the inception of the development process, sponsors will be reminded continually to assess the availability and constitution of the likely sources of project capital. A common goal of sponsors is to minimize and delay the funding of the highest cost of capital, the sponsors' equity, and to leverage the project with the cheapest source of external financing, which, depending on market conditions and the project, is likely to be long-tenor senior debt from the commercial bank market, eligible financing from public sector funding institutions, or the capital markets [17]. The financing method is a short-term method of transferring capital to the country, because after the loan is repaid, the principal of the capital must be returned with the interest; therefore, the most important condition in receiving a foreign currency loan is to allocate it to projects that are economically justified and have a reasonable rate of return on investment [28]. In general, two methods, including autonomous and nonautonomous financing, are used to finance projects. In the self-governing method, the credit receiving company must be able to export the goods to repay the facility installments in foreign currency as shown in Figure 7 [29].
Engel and Fischer's [30] research about investment terms means agreeing to pay the price of technology and equipment received in return for a long-term offer. They supply or guarantee the sale of their country's products, and it is considered to be the worst type of borrowing, especially for large-scale borrowing. Because the repayment period of this type of borrowing is very short, and usually even if they become productive capital, there is not enough opportunity for the production cycle of the same capital to circulate, and therefore, the committed country is obliged to use other financial resources to repay the loan. This puts severe pressure on the borrower's financial resources in the short term. In non-loan methods, the return of principal and interest is not guaranteed by the banking system or the government, and the risk of return of capital and resources is borne by the investor. Non-loan methods are the same as investment methods. In the investment method, the financier (investor), by accepting the risk of using financial resources in the activity or project, expects a return on the principal and profit of the invested resources from the economic performance of the project. Financing from any source and in any way causes the company to be indebted to members outside it. Of course, it is necessary to pay attention to the fact that being in debt to a suitable ratio of the company's capital is usually an advantage for that company (Christopher, 


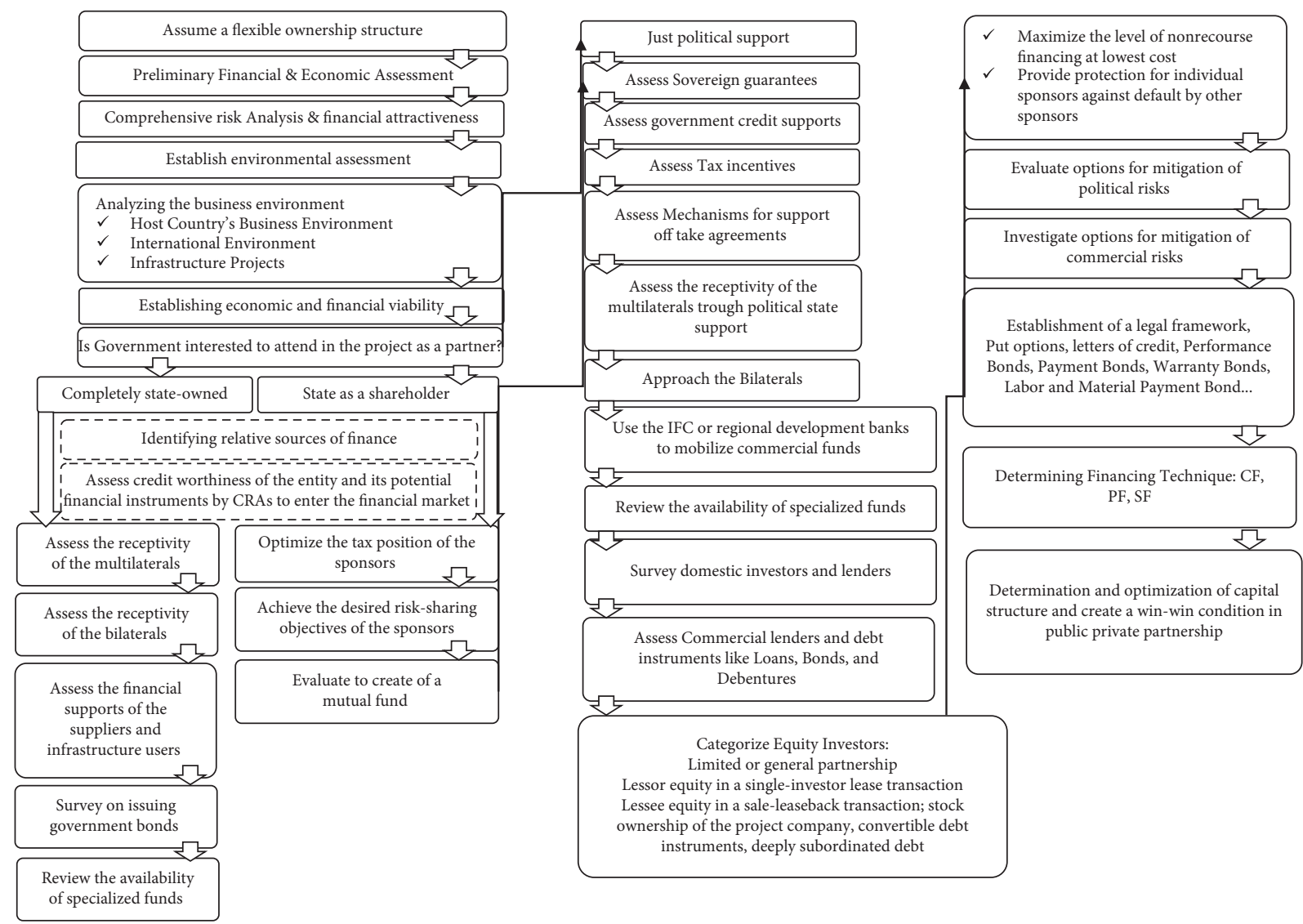

FIgURE 7: Conceptual Framework on the effects of ownership structure on corporate.

\begin{tabular}{|c|c|c|}
\hline Determining the ownership structure & Identifying sources of finance & Preparing the security package \\
\hline $\begin{array}{l}\text { Conceptual step } \\
\text { Deciding on } \\
\checkmark \quad \text { Complete state ownership } \\
\checkmark \quad \text { Complete private ownership } \\
\checkmark \quad \text { PPP }\end{array}$ & 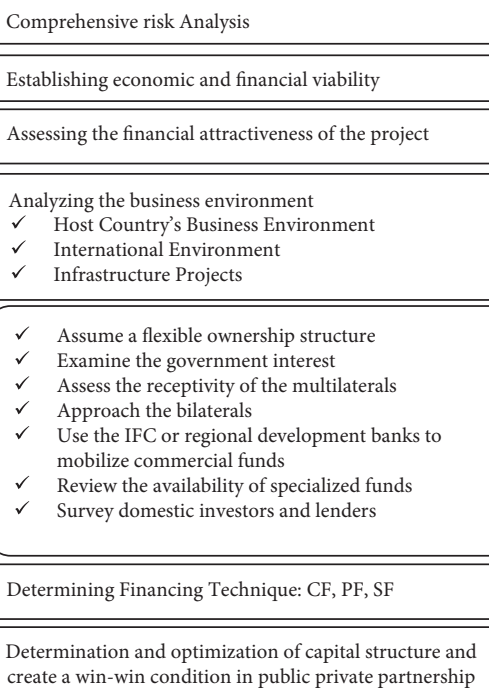 & 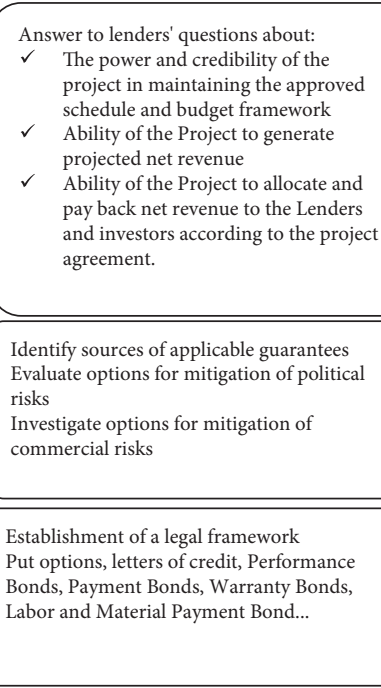 \\
\hline
\end{tabular}

FIGURE 8: Three main steps of preparing financing package.

2013). While alternatives to traditional debt finance are particularly important for startups, high growth, and innovative SMEs, the development of alternative financing techniques may be relevant to the broader population of SMEs and microenterprises.
In order for this rate of return to be reasonable and not become too high, the owner of the capital must be sure that the minimum desired profit will be met. This level of confidence is known as risk. The lower the company's risk, the lower the expected rate of return of the lender or 
investor. At best, this rate is 2 to 3 percent higher than government bonds at the time. Of course, hedge funds and venture capital also lend at lower rates. Venture capital funds, for example, support the entrepreneur by granting scheduled capital to him or her and do not claim losses or expenses incurred up to that point if the plan fails. Fortunately, in our country, these funds are in the early stages of their activities. The list of support funds and various sources of financing is available in the database, and their scope of work is also introduced (Figure 8). In the course of this earlier study, it was revealed that a lack of awareness and understanding on the part of SMEs, financial institutions, and governments of these alternative instruments, their modalities, and operations constitute a major barrier to their use.

\section{Conclusion}

One of the most basic needs of developing countries is economic infrastructure, which is the bedrock of growth and development in other sectors of the economy, as well as the lack of proper response to the need for financing in this sector, and economic development faces major problems and challenges. Developing countries have difficulty financing their infrastructure projects, and designing optimal solutions for financing such projects is a basic need of these countries. These types of projects have two main characteristics that should be considered in the financing method. The first characteristic is long term, and the second characteristic is the huge cost of implementing these projects. Debt-based financing and property-based financing: governments in developing countries have so far preferred to finance debt through the first debt-based method, unaware that this type of financing and the choice of this method will cause many problems for the economy. Sukuk is an Istisna of Islamic securities that can be used in this type of financing, and with the ability to combine with other contracts, including rent and partnership, it will provide optimal financing for this type of projects. Paying attention to macroeconomic considerations in designing financing models has been neglected, despite its great impact in all areas. Attention to issues related to financial crises and economic stability, creating leverage in the economy, government budget deficit, inflation, and risk distribution among economic factors are among the issues that are affected by structures and financing models, so in this article, these considerations of the various models presented are also examined, and we will show that, by matching the financial flows of government projects with the real economy, especially in the field of infrastructure, macroeconomic damage can be avoided. What is being debated in the world today is the extent of the powers and responsibilities and the level of involvement of each public and private sector in projects, while in developing countries, such as Iran, publicprivate partnerships are still relatively unknown or at least relatively unknown. It is underused. Although Iran is familiar with such a pattern in the field of energy, organizations such as municipalities need to enter into these issues due to the severe lack of financial resources and poor management in the implementation of large infrastructure projects. Public-private partnerships in the infrastructure development are relatively new experiences in many developing countries. Although governments have taken various steps to promote public-private partnerships, the lack of capacity in countries is still a major obstacle to such projects. The development of guidelines and information resources in this field is one of the effective measures to build capacity and eliminate possible ambiguities and misunderstandings about public-private partnership.

\section{Data Availability}

Requests for access to these data should be made to the corresponding author (ravanshadnia@srbiau.ac.ir).

\section{Conflicts of Interest}

The authors declare that there are no conflicts of interest regarding the publication of this paper.

\section{References}

[1] S. Runger, The Effect of Shareholder Taxation on Corporate Ownership Structures, Springer Fachmedien Wiesbaden, Graz, Austria, 2012.

[2] Asian Development Bank, Public-Private Partnership Operational Plan 2012-2020: Realizing the Vision for Strategy 2020-The Transformational Role, Asian Development Bank, Mandaluyong City, Philippines, 2012.

[3] E. R. Yescombe, Public-Private Partnerships: Principles of Policy and Finance, Elsevier, Butterworth-Heinemann, Oxford, United Kingdom, 2007.

[4] S. A. Salah, "Analyzing engineering-related delays using quality function deployment in construction projects," Civil Engineering Journal, vol. 6, no. 9, 2020.

[5] A. Bratko, D. Oleshko, A. Datskov, V. Vychavka, O. Olytskyi, and I. Balytskyi, "Use of the SWOT analysis in the field of national security planning," Emerging Science Journal, vol. 5, no. 3, pp. 330-337, 2021.

[6] H. Razavi, Financing Energy Projects in Developing CountriesPenn Well, Pennwell, Tulsa, Oklahoma, USA, 2007.

[7] A. Akintoye and M. Beck, "Introduction: perspectives on PPP policy, finance and management," in Policy, Finance and Management for Public- Private Partnerships, A. Akintoye and M. Beck, Eds., Blacwell Publishing Ltd., NJ, USA, 2009.

[8] E. R. Yescombe, Principles of Project Finance, Academic Press is an imprint of Elsevier, NX Amsterdam, The Netherlands, 2014.

[9] D. Morea and M. Balzarini, "Financial sustainability of a public-private partnership for an agricultural development project in Sub-Saharan Africa," Agricultural Economics, vol. 64, no. 9, pp. 389-398, 2018.

[10] D. Morea and M. Balzarini, "Bankability of a public private partnership in agricultural sector: a project in Sub Saharan Africa," Agricultural Economics, vol. 65, no. 5, pp. 212-222, 2019.

[11] L. Martiniello, D. Morea, F. Paolone, and R. Tiscini, “Energy performance contracting and public-private partnership: how to share risks and balance benefits," Energies, vol. 13, no. 14, 2020.

[12] R. Morrison, The Principles of Project Finance, Gower publishing, Aldershot, United Kingdom, 2012. 
[13] L. Hoffman, The Law and Business of International Project Finance: A Resource for Governments, Sponsors, Lenders, Lawyers, and Project, Cambridge University Press, Cambridge, United Kingdom, 2nd edition, 2001.

[14] K. Walsh, Public Services and Market Mechanism: Competition, Contracting and the New Public Management, MacMillan Press Ltd., London, United Kingdom, 1995.

[15] J. B. Miller, "Applying multiple project procurement methods to a portfolio of infrastructure projects," in Procurement Systems: A Guide to Best Practice in ConstructionE \& FN Spon, London, United Kingdom, 1999.

[16] A. Kramer and P. Fusaro, Energy and Environmental Project Finance Law and Taxation_ New Investment Techniques, Oxford University Press, Oxford, United Kingdom, 2010.

[17] J. Dewar, International Project Finance_Law and Practice, Oxford University Press, Oxford, United Kingdom, 2011.

[18] J. E. Kwoka, Power Structure_ Ownership, Integration, and Competition in the U.S. Electricity Industry, Springer, Netherland, 1996.

[19] Ppiaf, "Public-Private Partnerships Reference Guide," 2014, https://ppiaf.org/ppp-resources.

[20] J. D. Finerty, Project Financing: Asset-Based Financial Engineering, Wiley, NJ, USA, 2007.

[21] J. E. Schaufelberger and I. Wipadapisut, "Alternate financing strategies for build-operate-transfer projects," Journal of Construction Engineering and Management, vol. 129, no. 2, pp. 205-213, 2003.

[22] S. Gatti, Project Finance in Theory and Practice: Designing, Structuring, and Financing Private and Public Projects, Elsevier, NY, USA, 2nd edition, 2013.

[23] R. Tinsley, Advanced Project Financing, Euromoney Institutional Investor, London, United Kingdom, 2014.

[24] S. M. Levy, Build, Operate, Transfer: Paving the Way for Tomorrow's Infrastructure, Wiley, NY, USA, 1996.

[25] X. Zhang, "Financial viability analysis and capital structure optimization in privatized public infrastructure projects," Journal of Construction Engineering and Management, vol. 131, no. 6, pp. 656-668, 2005.

[26] P. Lynch, Financial Modelling for Project Finance, Euromoney Institutional Investor PLC, United Kingdom, London, 2011.

[27] E. Bodmer, Corporate and Project Finance Modelling, Theory and Practice, Published by John Wiley \& Sons, Inc., Hoboken, N J, USA, 2015.

[28] S. Borins, Electronic Ticketing: Highway 407, Case Studies in Contracting. Outsourcing and Alternative Service Delivery and Their Impact on the Management FrameworkQueens University, Kingston, London, 2003.

[29] R. Hrab, Privatization: Experience and Prospects, University of Toronto, Toronto, Ontario, Canada, 2003.

[30] E. Engel and R. D. Fischer, A. Galetovic, the Economics of Public-Private Partnerships. A Basic Guide, Cambridge University Press, Cambridge, United Kingdom, 2014. 